\title{
薬物の経皮吸収測定法に関する検討
}

\author{
中 村 紘 一** 中 野 重 行*
}

（受付：1995 年 4 月 19 日）

\section{A Method for the Estimation of Percutaneous Drug Absorption in Man}

\author{
Koichi NAKAMURA* and Shigeyuki NAKANO* \\ * Department of Clinical Pharmacology and Therapeutics, Oita Medical University \\ Hasama-machi, Oita 879-55, Japan
}

The percutaneous absorption rate of the topical formulation of a drug (PAR) has been calculated and expressed in percentage using the amount of the drug applied (Da) and the amount of the drug collected (Dc) as in the following equation:

apparent $\mathrm{PAR}=(\mathrm{Da}-\mathrm{Dc}) / \mathrm{Da}$

where Dc is measured by swabbing the drug remaining on the skin after a certain period of time has passed following application. One problem is that after swabbing, still a slight trace of the drug remains on the skin, even when it is carefully swabbed, this trace might cause an erroneous estimation of PAR, especially for drugs with a low PAR. To improve the accuracy in the estimation of PAR, we introduced the idea of "collection rate at time 0 " into the above equation as follows:

collection rate at time $0=\mathrm{Dc}$ at time $0 / \mathrm{Da}$

corrected $\mathrm{PAR}=(\mathrm{Da}-\mathrm{Dc} /$ mean collection rate at time 0$) / \mathrm{Da}$

"Collection rate at time 0 " indicates the technical efficacy of swabbing the drug applied to the skin. With the above equations, we calculated the corrected PAR for $5 \mathrm{~g}$ of $1 \%$ omoconazole nitrate cream applied in a single dose to the skin of the subject's back over 24 hours in 9 healthy male volunteers. Three of the 9 volunteers served as the subjects for the calculation of "collection rate at time 0 ". The mean corrected PAR $( \pm \mathrm{SD})$ for $1 \%$ omoconazole nitrate cream was found to be $13.6( \pm 6.3) \%$. The difference between the corrected and apparent PAR ranged from 2.5 to $3.0 \%$. If this expanded equation is employed, it would make a large difference in the estimation of PAR of the topical formulation of a drug with a low PAR or a drug poorly absorbed by a particular individual. With the "collection rate at time 0 " incorporated into the calculation of PAR, even a simple calculation method using swabbing will provide more precise and useful information for pharmacokinetic studies of the topical formulation of a drug.

Key words : percutaneous drug absorption, calculation method, man, omoconazole nitrate

$*$ 大分医科大学医学部臨床薬理学 $\quad$ † 875-55 大分県大分郡㣣間町医大ヶ 丘 1-1 


\section{緒 論}

軟衰やクリーム率に使用されている薬物の経皮 吸収率の算出には, 塗布薬物量と回収薬物量の差 から次の式で計算し, 得られた值を百分率で表示 する方法がよく使われている ${ }^{1,2)}$.

\section{経皮吸收率 $=\frac{\text { 塗布薬物量 }- \text { 回収薬物量 }}{\text { 染布薬物量 }}$}

回収薬物量は，塗布してから一定の時間後に皮膚 表面の薬剤を拭きとって求める。この方法では, 「拭きとる」操作を行っても薬凨が皮膚表面に残る 可能性があり，この残存する薬片によって経皮吸 収率の算出に誤差を生じる。

そこで, 塗布した直後に「拭きとる」操作によっ て薬剤を回収して平均 0 時間回収率を別に求め, 経皮吸収率を求める際の回収薬物量をこれで補正 して，誤差を少なくする算出方法を検討した。

\section{方 法}

文書で同意を得た, 平均年齢 26 歳, 平均体重 $60.9 \mathrm{~kg}$ の健常男性 9 名を対象とした。抗真菌㓮の $1 \%$ omoconazole nitrate クリーム $5 \mathrm{~g}$ を背部の 皮膚, $20 \mathrm{~cm} \times 25 \mathrm{~cm}$ に均一になるように塗布し， 塗布部をガーゼで覆った．ガーゼは絆創槀で固定 した. 3 名の被験者では塗布後直ちにガーゼを除 き，微温湯で湿した別のガーゼで塗布部を均等に 5 回拭きとって皮䖉表面の薬剂を回収し，0 時間 回収率を算出した。 6 名の被験者では 24 時間塗布 部をガーゼで覆った状態を保った。薬剤適用中の

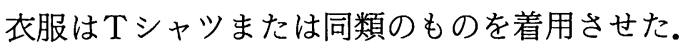
塗布 24 時間後に 0 時間回収率を算出した 3 名の 被験者と同様の操作により薬剤を回収した。薬剤 の回収は操作に熟練した同一人が行った。

Omoconazole nitrate は塗布部を覆ったガーゼお よび薬剤の回収に用いたガーゼを一緒にして抽出 し，HPLCによって測定した. HPLCによる回収 率は 99.8\%である。 0 時間回収率, 薬物のみかけ の経皮吸収率，および平均 0 時間回収率で補正し た経皮吸収率を次の式で算出し，得られた值を百 分率で表示した。
0 時間回収率 $=\frac{0 \text { 時間回収薬物量 }}{\text { 塗布薬物量 }}$

みかけの経皮吸収率 $=\frac{\text { 塗布薬物量一回収薬物量 }}{\text { 菬布葲物量 }}$

補正した経皮吸収率 $=$

塗布薬物量一回収薬物量/平均 0 時間回収率 浩布薬物量

\section{結 果}

それぞれの吸収率と0 時間回収率として Tab. 1 の結果を得た。 みかけの経皮吸収率と補正 した経皮吸収率との差は $2.5 \sim 3.0 \%$ あった。

Tab. 10 時間回収率と経皮吸収率

\begin{tabular}{ccc}
\hline 0 時間回収率 & みかけの吸収率 & 補正した吸収率 \\
\hline $96.8 \pm 0.6 \%$ & $16.4 \pm 6.1 \%$ & $13.6 \pm 6.3 \%$ \\
\hline
\end{tabular}

平均土標準偏差

\section{考 察}

ヒトで経皮吸収を測定するのに，簡便な方法と して「残差法」が使われている ${ }^{1,22}$. 皮膚表面に適 用(塗布)した薬物量と一定時間経過した後に残つ ている薬物量との差を「経皮吸収量」とする方法 である。この方法では, 薬物の回収が不適切であ ると吸収量の計算に誤差を生じる ${ }^{2}$.このため, 薬 物をできるだけ多く正確に回収する工夫がされて いる，それらのうち，放射性同位元素でラべルし た被験薬物を皮虔表面に適用し，一定時間経過し た後にエーテル，アセトン，石䩎水，水などで洗 浄して回収する方法，皮嘚の角質層を採取して薬 物を回収する方法はヒトでも使われている ${ }^{2 \sim 4)}$.こ れらの工夫は，経皮吸収を詳細に検討する場合に は適しているが，軟高剤，クリーム剤など外用剤 中の薬物の経皮吸収を測定するには問題点が多 い. とくに，第 1 相臨床試験のように健常人を対 象として検討する場合には不向きといえる。

適用直後に薬物を回収して 0 時間回収率を求 め, 適用後一定時間が経過した時点の回収率をこ れで補正すると測定誤差を小さくできる。この方 法は簡単であるためか，経皮吸収率の計算方法と 
Tab. 2 文献に報告されている抗真菌剤の回収率扔よび経皮吸収率 ${ }^{1 \sim 5)}$

\begin{tabular}{cccccc}
\hline 抗真菌剤 & 回収材料 & $\begin{array}{c}\text { 薬物回収率*1 } \\
\left(\begin{array}{c}\text { 平均士標準偏差 }) \\
(\%)\end{array}\right.\end{array}$ & $\begin{array}{c}\text { みかけの } \\
\text { 経皮吸収率*2 } \\
(\%)\end{array}$ & $\begin{array}{c}\text { 推測された } \\
\text { 経皮吸収率*3 } \\
(\%)\end{array}$ & $\begin{array}{c}\text { 差*4 } \\
(\%)\end{array}$ \\
\hline $\mathrm{A}$ & 脱脂綿 & $80.5 \pm 5.7$ & 19.5 & $10 \sim 15$ & $4.5 \sim 9.5$ \\
$\mathrm{~B}$ & へら, 脱脂綿 & $77.9 \pm 2.6$ & 22.1 & 20 & 2.1 \\
$\mathrm{C}$ & 脱脂綿 & $85.1 \pm 4.2^{* 5}$ & 14.9 & 10 & 4.9 \\
$\mathrm{D}$ & へら, 脱脂綿 & $87.5 \pm 14.7$ & 12.5 & 12.4 & 0.1 \\
$\mathrm{E}$ & へら, 脱脂綿 & $72.7 \pm 2.6$ & 27.3 & $20 \sim 25$ & $2.3 \sim 7.3$ \\
\hline
\end{tabular}

いずれも単回大量塗布後に「拭きとる」操作によって回収薬物量を求めた。

*1 回収薬物量/塗布薬物量によって計算した.

*2 薬物回収率の平均值から計算した。

*3 各報告者が考察の中で「技術的な問題」「誤差」を考慮したうえで推測した値.

${ }^{* 4}$ 「かけ経皮吸収率」と「推測された経皮吸収率」との差.

*5 原著では標準誤差で報告している。

して報告した論文は見当たらず，わずかに研究方 法の一部として記されているだけである ${ }^{4 \sim 6)}$. 補正 前後の経皮吸収率の差の検討についても報告には まとめられていない。

本研究の結果は，皮膚に塗布した薬剂を「拭き とる」操作によって回収しても皮店表面に残り, この残った薬剤により経皮吸収率の算出に誤差が 生じることを示している．経皮吸収率は塗布薬物 量と回収薬物量から算出した值であるから, 角質 層内に貯留している薬物量, 皮膚表面に残存して いる薬物量, 測定の過程で失われる薬物量などの 総和を含んだ值といえる。つまり「経皮吸収」さ れていない薬物量も含んで計算し，その結果得ら れた值を「経皮吸収」率としている。本研究で用 いた HPLC による回収率は $99.8 \%$ と高く, 回収 薬物量はこの回収率で補正していない。

従来の報告では，皮膚表面に残る薬物量や測定 の過程で失われる薬物量を考慮せずに, 軟高やク リーム剤に使用されている薬物の経皮吸収率を算 出している7 ${ }^{711)}$. 報告されている他の抗真菌郕の 経皮吸収率を Tab. 2 にまとめた。表中の「みかけ の経皮吸收率」は，いずれも皮膚表面に残る薬物 量で補正していない経皮吸収率で，その值は 12.5 27.3\%程度である.「推測された経皮吸収 率」は，各報告者が報告の考察の中で経皮吸収率 として推測した值を示している。薬䎟を回収する
際の「拭きとる」操作の「技術的な問題」や「誤 差」を考慮した推測值である. 回収率から算出し た值よりも低く推測しており,「みかけの経皮吸収 率」との差は 0.1 9.5\%である. 経皮吸収率を推 測するにあたって，各報告者が考察の中で述べて いる部分またはその要旨を各抗真菌剤ごとに Tab. 3 にまとめた. 皮膚表面に薬郕が残っている 可能性を懸念しているが，いずれの報告者も残存 薬物量を測定してはいない. 抗真菌剤以外の薬剤 でも 0 時間回収率を全く考慮せずに，残差を単純 に「経皮吸収量」としている報告が散見され $3^{12,13)}$.

「みかけの経皮吸収率」と平均 0 時間回収率で 「補正した経皮吸收率」の差は, 次の式で表される。

みかけの経皮吸収率一補正した経皮吸収率=

$$
\frac{\text { 回収薬物量 }}{\text { 叙布薬物量 }} \times\left(\frac{1}{\text { 平均 } 0 \text { 時間回収率 }}-1\right)
$$

したがって，一定の精度や熟練度で薬剤が塗布， 回収され，塗布薬物量と 0 時間回収率の值のばら つきが小さい場合には, 回収薬物量が大きいと「み かけの経皮吸収率」と「補正した経皮吸収率」の 差は大きくなる，すなわち，経皮吸収率が小さい 薬物や吸収量が少ない被験者では, 吸収率を算出 する際に皮膚表面に残る薬物量の影響を受ける。

$\lceil 0$ 時間回収率」は薬剛を回収する人の熟練度を 
Tab. 3 各報告者の経皮吸収率に関する考察

\begin{tabular}{|c|c|}
\hline 抗真菌剤 & 経皮吸収率に関する考察 \\
\hline A & 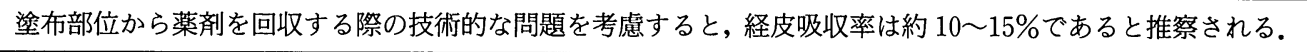 \\
\hline $\mathrm{B}$ & 薬剂を回収する際の技術的な問題等を考虑しても, 塗布量の約 $20 \%$ は皮虙中へ移行したものと推察される. \\
\hline $\mathrm{C}$ & $\begin{array}{l}\text { 単回投与試験の回収率は } 85.1 \%, \text { 反復投与試験第 } 1 \text { 日目の回収率は } 93.1 \% \text { で, この差は回収方法を変更した } \\
\text { ためである. } 7 \text { 日間の反復投与によっても回収率に大きな変化はなく,その平均は } 90.7 \% \text { たっった.したがっ } \\
\text { て経皮吸収率は約 } 10 \% \text { と考えられた. }\end{array}$ \\
\hline $\mathrm{D}$ & $\begin{array}{l}\text { 回収率の低い } 1 \text { 例を計算に加えると平均回収率は } 87.6 \% \text { (除くと } 93.4 \% \text { )であり, 塗布量の約 } 12.4 \% \text { は皮成 } \\
\text { へ移行したと推察された. }\end{array}$ \\
\hline $\mathrm{E}$ & 多少の未回収部分の誤差を考慮しても，約 20〜25\%は吸収された可能性がある. \\
\hline
\end{tabular}

示す指標でもある.「拭きとる」操作のばらつきは 操作の日内変動というべきもので, 今回, 同一人 によって回収して得た 0 時間回収率の変動係数は $0.6 \%$ あ゙あた。 0 時間回収率を求める際の被験者 数は回収率の推定の精度に関係する。0 時間回収 率は当然個々の薬郕によって異なるから, 薬剤ご とに求めて補正する。

薬剤を適用する部位の面積が小さい場合には, 被験者ごとに 0 時間回収率を求める適用部位を設 けて補正する，軟高剤やクリーム剤を広い面積に 大量に塗布して，経皮吸収や毒性について検討す る場合には, 別の被験者で平均 0 時間回収率を求 めて補正する．別の被験者で求めるのは，0時間 回収率を求めるための塗布部位と経皮吸収を検討 するための塗布部位を隣接して別に設けるのが難 しいためと，0 時間回収率を求めるのに塗布した 薬剂が皮膚表面に残存し，その後の経皮吸収の測 定に影響するのを避けるためである.

皮虞表面に塗布した薬剤を回収するには三つの 方法がある．湿った脱脂綿で拭きとる，へらで擦 りとったのち湿った脱脂綿で拭きとる, そして著 者らが用いた湿ったガーゼで拭きとる方法であ る. 抗真菌剤 $\mathrm{C}$ の報告者は, 湿った脱脂綿を用い る方法からゴム製のへらと湿った脱脂綿を併用す る方法に変えたところ, 回収率が $85.1 \%$ から 93.1\%に改善したと述べている。へらで擦りとる 方法では回収の際，角質層の上層を剥離している 可能性があるから，回収率が高くなったとも考え られる.ガーゼで拭きとる方法でも回収の際，角
質層の上層を剥離している可能性がある。一方, 脱脂綿で拭きとる方法では水で湿した脱脂綿の繊 維の間隙が密であるため, 拭きとった薬剤ですぐ に間隙が埋まり，拭きとる操作を繰り返しても塗 布面から薬剤が十分に回収されないのではないか と推測される。これに対してガーゼの瀻維は間隙 が粗なので，拭きとった薬剤で間隙がすぐ埋まる ことはないであろう。

「拭きとる」操作によって経皮吸収率を算出する 方法は簡便で，第 1 相臨床試験のようなヒトを対 象にした試験にも用いることができるから，皮夙 表面に残存する薬物量を考慮した算出方法の工夫 を行えば，より正確な経皮吸収率の算出に役立つ 方法である。

\section{結 論}

経皮吸収率の算出に際して, 皮膚表面に残存す る薬物量を考慮すると従来の方法より正確な情報 を得ることができる。

\section{文 献}

1) Nogami, H., Hasegawa, J. and Hanano, M. : Studies on ointments: A new simplified determination method for percutaneous absorption of ointments. Pharm. Bull., 4 :347-352 (1956).

2) Shah, V.P., Flynn, G. L., Guy, R. H. et al. : In vivo percutaneous penetration/absorption. Int. J. Pharm., 74 : 1-8 (1991).

3) Bucks, D. A. W., McMaster, J. R., Maibach, H. I. et al. : Bioavailability of topically administered 
steroids : A “mass balance" technique. J. Invest. Dermatol., 91 (1) : 29-33 (1988).

4) Yano, T., Nakagawa, A., Tuji, M. et al. : Skin permeability of various non-steroidal antiinflammatory drugs in man. Life Sci., 39 (12) : 1043-1050 (1986).

5）塚本幸恵, 宇津園子, 土屋雅勇ほか：ヒトにおける 簡易経皮吸収測定法の考案- $2 \%$ アスピリン軟膏へ の適用一. 病院薬学, 17:198-203 (1991).

6）夏木令子, 曽根知道, 松尾理枝ほか：インドメタシ ンの経皮吸収における基剤の影響（第 1 回経皮吸収 型製剤シンポジウム ポスターセッション抄録). Ther. Res., $3: 50$ (1985).

7）伊藤正俊, 大西明弘：健康な成人男子に対する抗真 菌剂 M-732 (Liranaftate) クリームの単回および 反復大量塗布試験. 薬理と治療, 20：4501-4508 (1992)。

8）伊藤正俊, 宇治康明：健常成人に対する抗真菌剤
KP-363 (Butenafine Hydrochloride)クリームの単 回および反復大量塗布試験. 基礎と臨床, 24:32393246 (1990).

9）大西明弘, 安田耕太郎, 竹田秀一ほか：外用抗真菌 薬 TJN-318 クリームの安全性並びに薬物動態に関 する検討. 臨床医薬, 8 ：799-811 (1992).

10）小林孝志，西川武二：健常人に対する抗真菌薬 Ketoconazole クリームの単回塗布試験. 薬理と治 療, 19:1857-1861（1991）。

11）須貝哲郎, 山田秀雄, 菅野浩一ほか：抗真菌剤 710674-S のヒトにおける体内動態の検討. 基礎と 臨床, 18：6533-6543（1984）。

12）横田秀雄, 北村正孝, 佐々木富男：L-740 の生体内 動態および安全性に関する検討. 基礎と臨床，26： 4711-4722 (1992).

13）星野伸夫, 芝田信人, 卜部頼人ほか：リドカインと テトラカインの共融混合物を用いた局所麻酔軟亭の 調製. 薬蝺学, 51：158-165 (1991). 